\title{
The Effectiveness of Learning Method Drawing on The Development Visual Language of Children Picture 6-9 Years (Case Study Elementary School Bandung City)
}

\author{
Maya Purnama Sari ${ }^{1}$, Dian Rinjani ${ }^{2}$ \\ ${ }^{1,2}$ Multimedia Education Majors, Cibiru Campus University of Education Indonesia \\ Jl. Raya Cibiru Km.15, Bandung 40393 \\ E-mail: ${ }^{1}$ mayapurnama@upi.edu, ${ }^{2}$ dianrinjani@upi.edu
}

\begin{abstract}
Drawing learning methods have the aim to develop children's creativity, both formal and informal schools. Observations made in elementary schools and creative studios have two different types of images, namely storytelling and patterned pictures. Some of the images look engineered, so they do not look typical of children's drawings. The purpose of this study was to determine the effectiveness of drawing learning methods in children aged 6-9 years in formal schools and the suitability of the drawing results to the development of the visual language of children's drawings. The study used a mixedmethod, descriptive qualitative by collecting photos, videos, behavioral observations. Quantitative by way of tabulating visual language to analyze the picture has a scheme in accordance with the development of the visual language of children's drawings. The theory used is the theory of drawing learning methods and the theory of visual language. The research findings namely, the method of learning to draw free and correlated expressions is very effectively used, because it focuses the child on the process rather than the result. The results of drawings in two schools have results that are in accordance with the stages of the development of the visual language of children's drawings. The method can be used as a reference in learning in formal schools to develop children's creativity. The direct method is not appropriate to use at the elementary school level because it makes the results of children's drawings not in accordance with the language development scheme.
\end{abstract}

Keywords: formal school, drawing learning method, children's drawing language

Efektivitas Metode Pembelajaran Menggambar Terhadap Perkembangan Bahasa Rupa Gambar Anak Usia 6 - 9 Tahun (Studi Kasus Sekolah Dasar Kota Bandung)

\begin{abstract}
Abstrak
Metode pembelajaran menggambar memiliki tujuan untuk mengembangakan kreativitas anak, baik sekolah formal maupun informal. Pengamatan yang dilakukan di sekolah dasar dan sanggar kreatif terdapat dua jenis gambar yang berbeda, yaitu gambar bercerita dan berpola. Beberapa gambar terlihat direkayasa, sehingga tidak tampak kekhasan gambar anak. Tujuan penelitian untuk mengetahui efektivitas metode pembelajaran menggambar pada anak usia 6-9 tahun di sekolah formal serta kesesuaian hasil gambar terhadap perkembangan bahasa rupa gambar anak. Penelitian menggunakan metode campuran, kualitatif desktiptif dengan mengumpulkan foto, video, observasi perilaku. Kuantitatif dengan cara tabulasi bahasa rupa untuk menganalisis gambar tersebut memiliki skema yang sesuai dengan perkembangan bahasa rupa gambar anak. Teori yang digunakan adalah teori metode pembelajaran menggambar dan teori bahasa rupa. Temuan penelitian yaitu, metode pembelajaran menggambar ekspresi bebas dan berkorelasi sangat efektif digunakan, karena memfokuskan anak pada proses bukan hasil akhir. Hasil gambar pada dua sekolah memiliki hasil yang sesuai dengan tahapan perkembangan bahasa rupa gambar anak.
\end{abstract}


Metode tersebut dapat dijadikan acuan dalam pembelajaran di sekolah formal untuk mengembangkan kreativitas anak. Metode langsung kurang tepat digunakan pada tingkat sekolah dasar karena membuat hasil gambar anak tidak sesuai skema perkembangan bahasa rupa gambar anak.

Kata kunci: sekolah formal, metode pembelajaran menggambar, bahasa rupa gambar anak

\section{INTRODUCTION}

Pictures for children are a play of the imagination. Drawing activities become fun, wherever, whenever, and even with any media. The uniqueness of the child's drawing is a character because of its different development. Some children have appropriate creative development, some are slower, and some are faster. A creative process is the goal of learning to draw, this becomes important. Not just values in the form of numbers which are the goal of learning to draw for children.

Formal education at the elementary school level already has standard guidelines, namely the curriculum (Sukmadinata, 2004). However, the curriculum can be developed by each school according to the needs of the school environment. Based on preliminary observations that have been made at three formal schools and two creative art studios in the city of Bandung, it shows that pictures of the first and second-grade children look expressive and tell stories. Whereas in the third-grade children's drawings, there are patterns, especially in coloring the pictures. The appearance of this pattern is contrary to the scheme of developing children's visual language drawings. The process is the main thing in drawing; it indicates that some parts of the process experience different things.

The development of the visual language of children's drawings from the Fine Language theory expressed by Prof. Primadi Tabrani, regarding the characteristics of children's drawings from the age of $0-13$ years is very in accordance with the characteristics of children's drawings so that it becomes a reference in this study because it looks more specifically at the results of scribbles of children, not on the psychological side of the child when drawing (Tabrani, 2014). The results of this drawing are then adjusted to the drawing learning methods used by each teacher. The selected school has teachers with a background in fine arts education so that they have an in-depth understanding of art learning.

From the presentation of the discovery of patterns in children's drawings, this study will focus more on drawing learning methods that can be in accordance with the scheme of developing children's visual language drawings, Prof. theory. Primadi Tabrani.

The sample of this research is public and private elementary schools throughout the city of Bandung. The criteria sought are schools with an A accreditation value with exceptional teachers in fine arts education. Four schools 
were obtained, including two public elementary schools (Banjarsari 5 and Isola) and two private elementary schools (Kuntum Cemerlang and UPI Laboratory Elementary School).

\section{METHOD}

Based on the research problem, the research method used is mixed methods (quantitative and qualitative), along with the analysis used in each method.

1. The quantitative analysis method is by tabulating the visual language of the wimba and expressing it distinctively. To get the amount of wimba that is in accordance with the child's visual language development scheme so that an indication of the effect of the learning method can be seen.

2. The method of qualitative analysis by observing the behavior of the teacher for more detailed learning and observing the behavior of the child to determine the process of creation that occurs every time learning takes place

3. Qualitative analysis method with in-depth interviews with teachers to get a lot of information on the reasons for implementing irregular and in-depth learning and interviews with children when drawing to find out the story of each picture made.

\section{Image Analysis}

The analysis carried out with visual language describes the image and its content in a unique way to determine its suitability with the development of the visual language of the child's image. Like the analysis in the following picture:

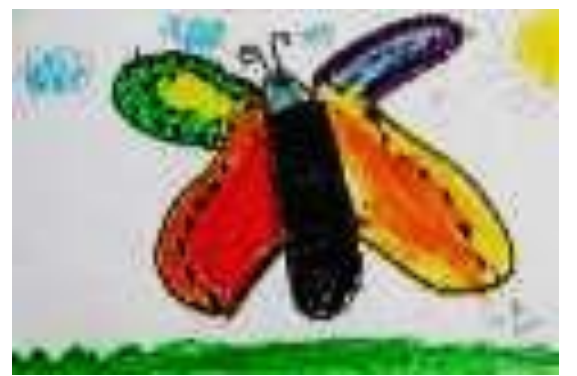

Picture 1. Butterflies descend on the garden (Marlon, 6 Years)

Table 1. Description of events and content of image

\begin{tabular}{ccl}
\hline No & \multicolumn{1}{c}{ Incident } & Fill in the image \\
\hline 1. & Butterflies descend on the garden & -1 Sun \\
& -3 Clouds \\
& -1 green grass \\
& -2 large lower wings \\
& -2 small upper wings \\
\hline
\end{tabular}


Table 2. Wimba Method Analysis

\begin{tabular}{|c|c|c|c|c|c|c|c|c|c|c|c|}
\hline \multirow{2}{*}{ Image Name } & \multicolumn{3}{|c|}{ W-I } & \multicolumn{2}{|c|}{ W-II } & \multirow{2}{*}{$\begin{array}{c}\mathrm{W}-\mathrm{III} \\
1\end{array}$} & \multicolumn{2}{|c|}{ W-IV } & \multicolumn{3}{|c|}{ W-V } \\
\hline & 1 & 2 & 3 & 1 & 2 & & 1 & 2 & 1 & 2 & 3 \\
\hline $\begin{array}{l}\text { Butterflies descend } \\
\text { on the garden }\end{array}$ & 3 & 3 & 2 & 1 & 2 & 1 & 1 & 4 & 1 & - & 4 \\
\hline Scene & & & & & & & & & & & \\
\hline $\begin{array}{l}\text { Butterflies fly in the } \\
\text { garden with their } \\
\text { beautiful wings } \\
\text { Inner Expression } \\
\text { (Tata Ungkap Dalam) }\end{array}$ & & & & & & & & & & & \\
\hline Enlarged & & & & & & & & & & & \\
\hline
\end{tabular}

Flying butterflies will stop in the garden during the day to rest

- Enlarged lower wings and body to show that the lower part will reach the ground earlier - Black dots represent wing decorations.

\begin{tabular}{ccc}
\hline \multicolumn{2}{c}{ Development of Children's Drawing Visual Language } \\
\hline $\begin{array}{l}\text { Schemes develop along with the } \\
\text { development of sensory integration, the } \\
\text { development of the concept of space and } \\
\text { time. }\end{array}$ & $\begin{array}{l}\text { Land line, not yet } \\
\text { perspective, simplified } \\
\text { (stylized). } \\
\text { Various visual } \\
\text { languages are used all } \\
\text { at once, head-feet }\end{array}$ \\
\hline
\end{tabular}

The image corresponds to the development of the visual language of the child at the age of 6 years

Table 3. Explantion Wimba Method Analysis

Source: Tabrani, (2012: 12)

\begin{tabular}{llll}
\hline Wimba & & & \\
\hline I & Retrieval Size & 1 & Enlarged \\
& & 2 & Minimized \\
& & From feet to head \\
\hline II & Take-up Angle & 1 & Various looks \\
& & 2 & X-Ray \\
\hline III & Scale & 1 & Gigantic size \\
\hline IV & Depiction & 1 & Incident \\
\hline & & 2 & Various looks \\
& & 3 & Representative \\
\hline V & How to See & 1 & Direction see right to left or kinda \\
& & 2 & Direction see top to bottom or kinda \\
& 3 & Direction see middle to edge \\
& 4 & Direction see edge to center \\
& & 5 & Direction see with one another \\
& & 6 & Direction see chase \\
& & 7 & Direction see average \\
& & 8 & Direction see get around \\
& 9 & Direction see visible from anywhere \\
\hline
\end{tabular}




\section{RESULTS}

There are two theories used in analyzing this problem: the theory of the method of learning fine arts and the theory of the development scheme of the visual language of children's drawings.

\section{Theory of Fine Arts Learning Methods}

The learning method is divided into two groups, namely theoretical and practical; in the practical method of learning art De 'Francesco (1958: 133-141) summarize four types of art learning methods used by elementary to high school levels. These methods include directed teaching, free expression (free expression), core teaching, and correlated teaching. The following is a discussion of the four methods. This method is appropriate when used in junior and senior high school education to teach techniques to create fine artwork and practice persistence appropriately.

This learning method needs to be considered for the continuity of art learning, be it in elementary to high school levels, by paying attention to psychology on child development and reasonable goals for students.

\section{a. Directed Teaching}

The direct learning method is so rigid because the learning process occurs in only one direction. The position of the teacher is to provide a lot of knowledge, techniques and other things that dictate the details. Meanwhile, students become objects to receive all knowledge from their teachers. The principle of direct learning is like the understanding of children's education tabula, where children are likened to empty vessels that must be filled and can be filled with all forms of knowledge, assuming the child does not know what is given. The methods used in direct teaching are modelling, stick figure, and global (model). Direct teaching aims to expect and want their students to be able to master certain techniques to produce identical, perfect products.

\section{b. Free Expression Method}

A free expression method is a teaching approach that leads to spontaneity from students, and teachers do not dominate everything that comes from itself. Teaching methods by demonstration, exploration or demonstration-exploration and experimentation are used in this method. Still, the teacher or coach who will apply this method must understand the aspects of the development of children's creativity and psychology to be able to place the word 'free' correctly. With this method, teachers distance themselves and do not interfere with the activities of their students. The process of implementing this method runs informally in the world of education. The presence of teachers has a very small role, even almost unnecessary. 
This condition is very meaningful for students who have high motivation to learn, but for students who have low motivation, this condition can be misused for playing. This method is starting to be widely applied in creative art studios to develop children's personalities.

\section{c. Core Teaching}

Teaching methods that prioritize problem solving, meet needs and want to change all attitudes and even certain social situations in a critical and creative way, so emphasize intelligence and intelligence to think on personal values. The form of artwork is not the main thing, but the development of creative concepts from artistic ideas is expected in the core learning method. So that there is a relationship between the development of core teaching methods from reading, writing and arithmetic with the core of skills, namely expecting to be able to solve various problems in people's lives. Not just being a scientist but can be a creative scientist or vice versa not just an artist but can be a knowledgeable artist to be able to solve life's problems creatively. This learning method began to be given to the high school and advanced school children, so it was not suitable for elementary school children.

\section{Theory of Children's Drawing Visual Language Development}

Children's drawings are unique with their stories and never a child's drawing is made the same. Even though the development of visual language, pictures of each child are similar. At each stage, boundaries exist for definite differences but are not always clear, as some children experience slower, faster processes that overlap and are overlooked. The development of this child is adapted from biogenetic theory which explains the present period of child development (ontogeny) and the acceleration of the early days of humankind (phylogeny), in prehistoric times, the next growth period will be influenced by the environment and culture. The scheme described is the child's visual language development from the way the child only describes the story, not related to geographical or cultural differences. The following describes a scheme for developing children's visual language images.

Table 4. Schematic of children's visual language development Source: Tabrani, (2012: 14)

\begin{tabular}{llll}
\hline No. & Age & \multicolumn{1}{c}{ Image development } & \multicolumn{1}{c}{$\begin{array}{c}\text { Development of Visual } \\
\text { Language }\end{array}$} \\
\hline 1. & $2-3$ & Smudge meaningless. & $\begin{array}{l}\text { New is the sensation of finger } \\
\text { imprints. }\end{array}$ \\
\hline 2. & $3-4$ & $\begin{array}{l}\text { The smudging starts to have } \\
\text { meant. }\end{array}$ & $\begin{array}{l}\text { Space, various times, various } \\
\text { spaces. }\end{array}$ \\
\hline 3. & $4-5$ & $\begin{array}{l}\text { Concerned with parts of the } \\
\text { object. }\end{array}$ & $\begin{array}{l}\text { Shifted, dynamic, looks typical, } \\
\text { certain parts of the object are } \\
\text { enlarged and others are ignored. }\end{array}$ \\
\hline
\end{tabular}




\begin{tabular}{lcll}
\hline 4. & $5-6$ & $\begin{array}{l}\text { Simple schematic, top-down } \\
\text { concept. }\end{array}$ & $\begin{array}{l}\text { Top-bottom, bottom edge = dirt } \\
\text { line. }\end{array}$ \\
\hline 5. & $6-7$ & $\begin{array}{l}\text { Schema development, as sense } \\
\text { integration develops. The } \\
\text { development of the concept of } \\
\text { space and time. }\end{array}$ & $\begin{array}{l}\text { The land line, there is no } \\
\text { perspective, is simplified (distilled). } \\
\text { Various visual languages are used } \\
\text { at once, head-foot. }\end{array}$ \\
\hline 6. & $7-8$ & $\begin{array}{l}\text { Prioritize the objects that are } \\
\text { concerned. }\end{array}$ & $\begin{array}{l}\text { The object of interest is magnified, } \\
\text { X-rays. }\end{array}$ \\
\hline 7. & $8-9$ & $\begin{array}{l}\text { Various time and space. } \\
\text { Background layer, plural earth } \\
\text { lines, twins, multiple images, laying } \\
\text { down, around, flat, decorative. }\end{array}$ \\
\hline 8. & $9-10$ & $\begin{array}{l}\text { The eye begins to function in } \\
\text { more detail. }\end{array}$ & $\begin{array}{l}\text { More detailed details of the object } \\
\text { being drawn. }\end{array}$ \\
\hline 9. & $10-11$ & $\begin{array}{l}\text { Images other than the result of } \\
\text { imagination, are records of } \\
\text { events. }\end{array}$ & $\begin{array}{l}\text { Seems to be a naturalist, but at the } \\
\text { same time the various "wars" in the } \\
\text { visual language are used. }\end{array}$ \\
\hline 10. & $11-13$ & $\begin{array}{l}\text { Crisis period when there is a } \\
\text { between the new eye senses and } \\
\text { the other senses. }\end{array}$ & $\begin{array}{l}\text { Feature: an image of overlapping } \\
\text { space appears (children are } \\
\text { confused between RWD and NPM } \\
\text { systems). }\end{array}$ \\
\hline
\end{tabular}

\section{Curriculum}

In terms of this defined curriculum is the Education Unit Level Curriculum (KTSP) effective from the 2006/2007 school year. Determination by the national education government (DEPDIKNAS) by providing guidelines for preparation or development, with the legal basis of UURI Number 20 of 2003 concerning the National Education System, Republic of Indonesia Government Regulation Number 19 of 2005 concerning National Standards Education, regulation of the Minister of National Education Number 22 of 2006 concerning Standards Contents for Primary and Secondary Education Units, National Education regulation No. 23 of 2006 concerning Graduate Competency Standards for Education Units and Regulation of the Minister of National Education Number 24 of 2006 concerning implementation Regulation of the Minister of National Education Number 22 of 2006 and Number 23 of 2006 (DIKNAS, 2014).

Feldman (1982: 21-45) in Duncum, Paul (2008), mentions inner varieties the curriculum used and should be able to be developed from time to time four types, including (1) Technology, (2) Psychology, (3) Anthropology and History, and (4) Aesthetics. However, in total the curriculum is applied according to its orientation, according to Miller and Seller (1985: 6-8), describing three basic orientations in implementation. Learning as an activity in implementing the curriculum, namely (1) Transaction Orientation, (2) Transaction Orientation, and (3) Transformation Orientation. Each school and teacher can apply an orientation to the needs of students or the goals of the school. 


\section{DISCUSSION}

\section{The Intensity of the Four Schools in Applying the Drawing Learning Method}

This data reduction was carried out to focus the teacher more intensely in applying the same learning method in the 16 learning sessions. The results will be found that three schools that more often use three drawing learning methods. The following are the results of the data obtained.

\section{a. Banjarsari 5 Elementary School}

The data results above show that Elementary School Banjarsari in class 1 uses $50 \%$ direct learning methods, free expression, and a correlation of $25 \%$, respectively. In grade 2, direct learning methods and 50\% balanced correlation. In grade 3 the application of the free expression learning method is $25 \%$ and $75 \%$ correlated. So, it can be concluded that the application of the correlated method in class 3 is more dominant than other classes, namely $75 \%$.

\section{b. Isola Elementary School}

The data results above show that the application of direct learning methods and free expression is balanced by $50 \%$ in grade 1 and class 2 . In class 3 , direct learning methods apply 50\%, while the free expression method and balanced correlation are $25 \%$.

So, it can be concluded that the application of the direct learning method is balanced in classes 1-3, and the application of balanced free expression in grades 1 and 2. So that there is no domination of the use of the chasing method in each class.

\section{c. Kuntum Cemerlang Elementary School}

The data results above show that in grades 1-3, the application of the overall free expression method is $25 \%$, in-class 1 , the application of the direct learning method is $50 \%$. In grades 2 and 3, the application of the direct learning method is more dominant, as much as $75 \%$. So, it can be concluded that the direct learning method is more dominant in grades 2 and 3.

\section{d. UPI Laboratory Elementary School}

The data result above indicate that the application of the free expression learning method dominates in grades $1-3$ as much as $75 \%$, besides that it is only applied. Direct learning methods in grades 1-3 are 25\%. It can be concluded that teachers in grades 1-3 mostly use the application of the free expression learning method.

Table 5. The intensity of the application of the drawing learning method

\begin{tabular}{llccc}
\hline No. & \multicolumn{1}{c}{ School Name } & Method & Class & Result \\
\hline 1. & Banjarsari 5 Elementary School & Korelasi & 3 & $75 \%$ \\
\hline 2. & Kuntum Cemerlang Elementary School & Langsung & 2 & $75 \%$ \\
\hline 3. & UPI Laboratory Elementary School & Ekspresi Bebas & 1 & $75 \%$ \\
\hline
\end{tabular}


From Table 5, it can be concluded that the school sample in this study was only three schools, namely Elementary School Banjarsari representing the correlated learning method in grade three, Elementary School Kuntum Cemerlang representing direct learning methods and Pilot UPI Laboratory Elementary School.

\section{a) Analysis of the Application of Learning Methods Banjarsari 5 Elementary School \\ Correlated Teaching Methods}

Free Expression learning methods are applied by third grade teachers at Banjarsari State Elementary School, Bandung.

\section{KTSP Curriculum - Class 3, Semester 2}

- Competency Standards: 9. Express yourself through works of art.

- Basic Competence: 9.1 Express yourself through imaginative pictures of the natural surroundings.

- Material: Collaboration in the field of civic studies, natural knowledge and Indonesian to be expressed in the form of drawing art.

- Presentation of material: Starting with a discussion about friendship, mutual love, cooperation (citizenship), then how the forest is in the afternoon and evening complete with the animals in the forest (Natural Knowledge).

- Story Contents: Tells the story of three children playing marbles by a river near the forest in the afternoon. While playing with marbles, one child fell into the river and then they saw wild animals in the river such as crocodiles and snakes.

- Instructions: Finish the story with their imagination on an illustrated image.

- Conditions: - The media used are pencils, markers, and crayons. If you are coloring, use a gradient technique.

The learning process in the third grade at Banjarsari 5 Elementary School is a development of the KTSP curriculum (Depdiknas, 2014); the development is in the theme of the material and learning methods. The curriculum approach used is grassroots because it seeks to develop the existing curriculum and its implementation with a transmission and transaction orientation. The combination of these two curriculum implementations is more dominant in transactions. In teaching and learning activities, the teacher initiates the transmission process of various sciences, intending to add insight. Then the implementation of transactions takes place so that students play an active role during learning. 
Table 6. Banjarsari 5 Elementary School

Drawing Learning Activities - Correlation Method
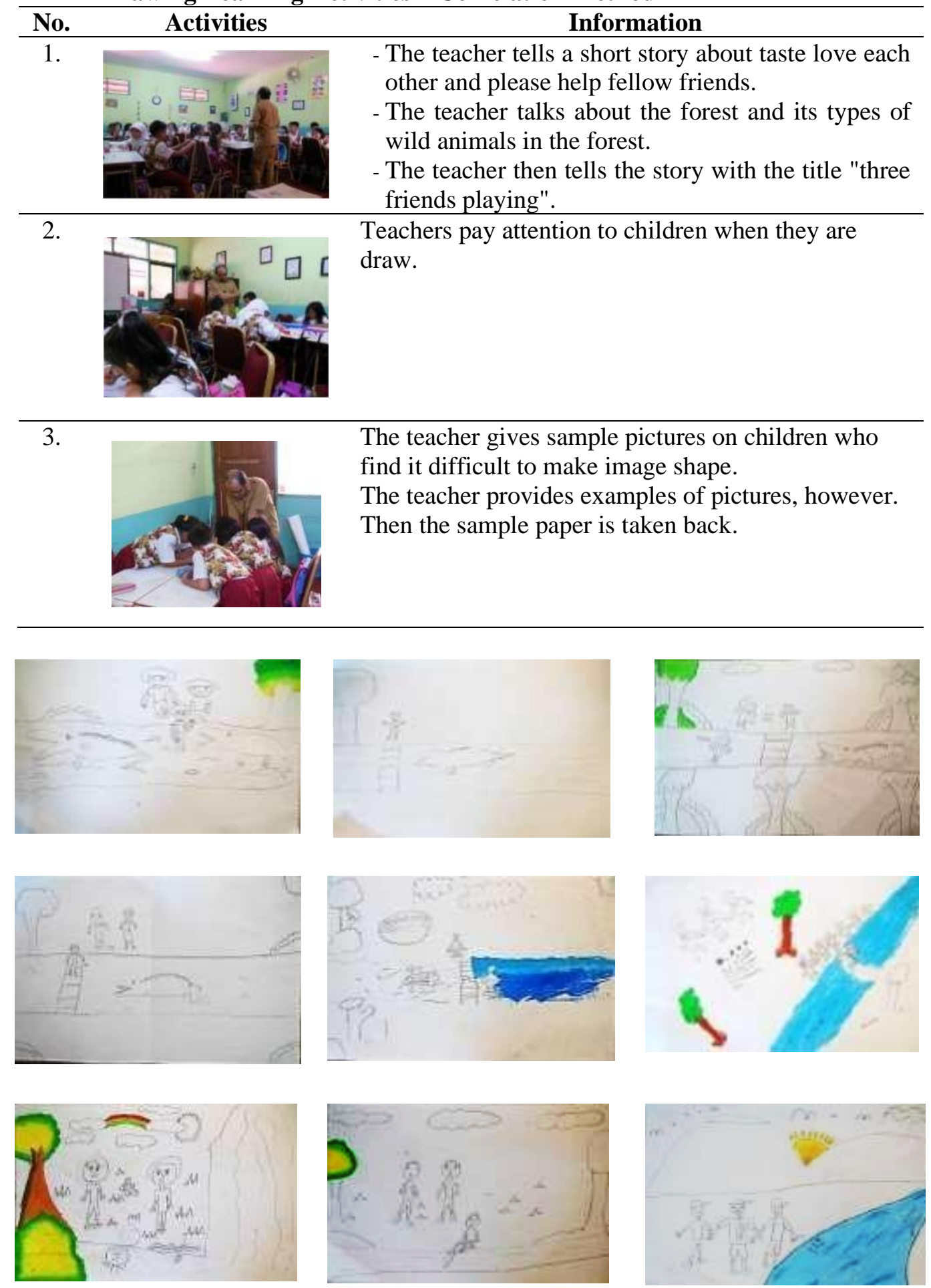

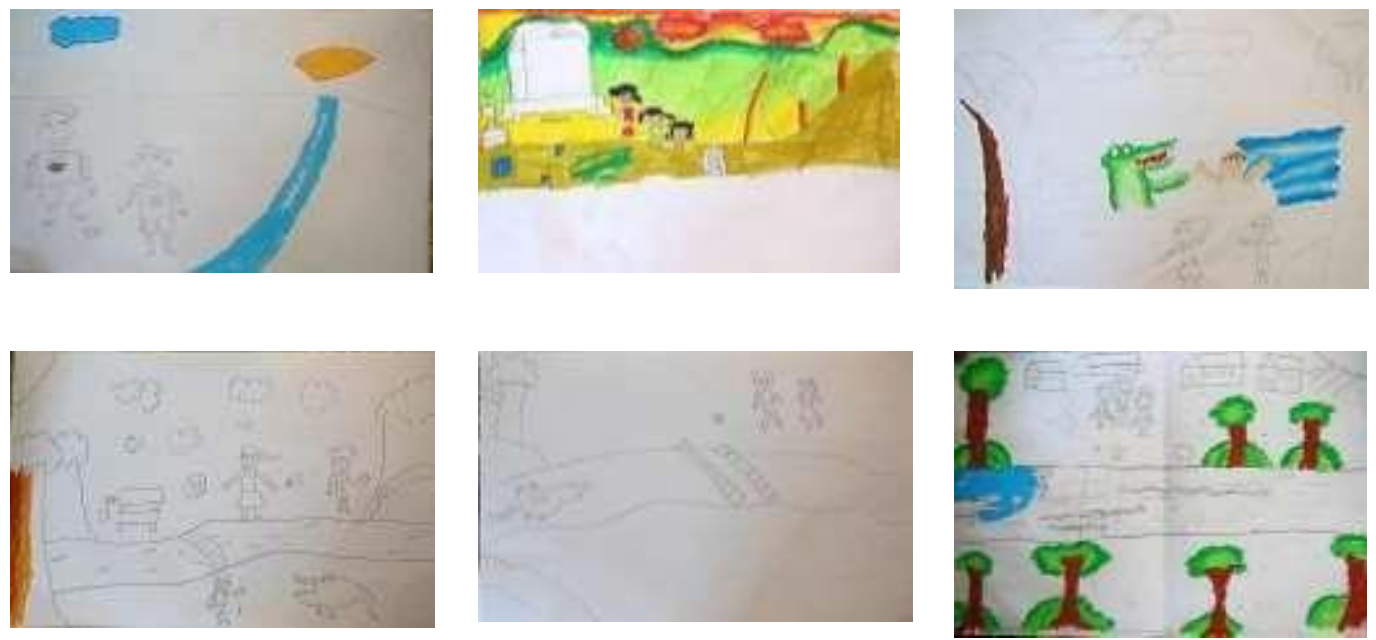

Picture 2. Image results Banjarsari 5 Elementary School Drawing Learning Activities - Correlation Method

\section{b) UPI Laboratory Elementary School}

\section{Free Expression Learning Methods (Free Expression)}

Free Expression learning method applied by grade 1 teachers at the Pilot UPI Laboratory Elementary School Bandung.

\section{KTSP Curriculum - Class 1, Semester 2}

- Competency Standards: 8. Express yourself through works of art

- Basic Competence: 8.1 Express yourself through expressive drawing art

- Material: Insect animals

- Instructions: Imagine what a butterfly would do. Pictures of butterflies and current activities.

- Conditions: The media used in drawing books, crayons, and pencils.

The learning process that took place in grade 1 at Pilot UPI Laboratory Elementary School is the development of the KTSP curriculum (Depdiknas, 2014), the development is in the material theme and learning method. The curriculum approach used belongs to grassroots, because it tries to develop the existing curriculum and its implementation with a transaction orientation. Teachers do not dominate much dialogue in teaching and learning activities; children play an active role in the teacher's stimulus. 
Table 7. Drawing Learning Activities in UPI Laboratory Elementary School Free Expression Method

\begin{tabular}{cc}
\hline No. & Activities \\
\hline 1. & $\uplus O$ \\
&
\end{tabular}

2.

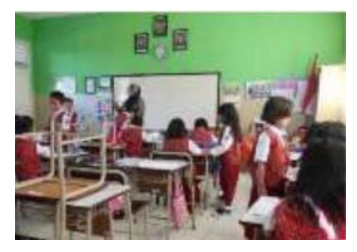

3.

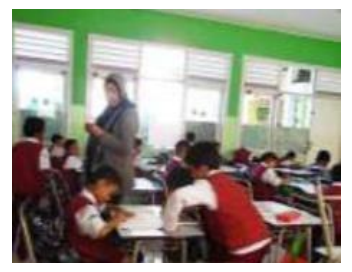

4.

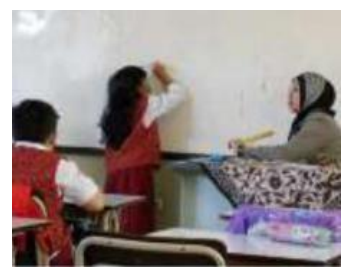

- The teacher invites children to draw.

- The teacher does not provide examples of pictures or shows an example of a butterfly shape.

Teachers pay attention and provide stimuli to some children who feel confused by asking, giving butterfly traits, give input if the butterflies are in some places

(parks, houses, streets).

The teacher gives the drawing material's theme and invites children to imagine becoming an insect animal (butterfly). Invite children to answer the question: What would you do if you become a butterfly? Where are you going? Whom are you going with?

After all the children have finished drawing, teachers provide opportunities to children

to draw on the board and tell the picture he made.
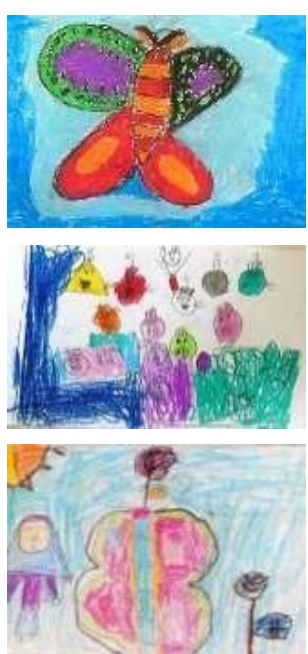
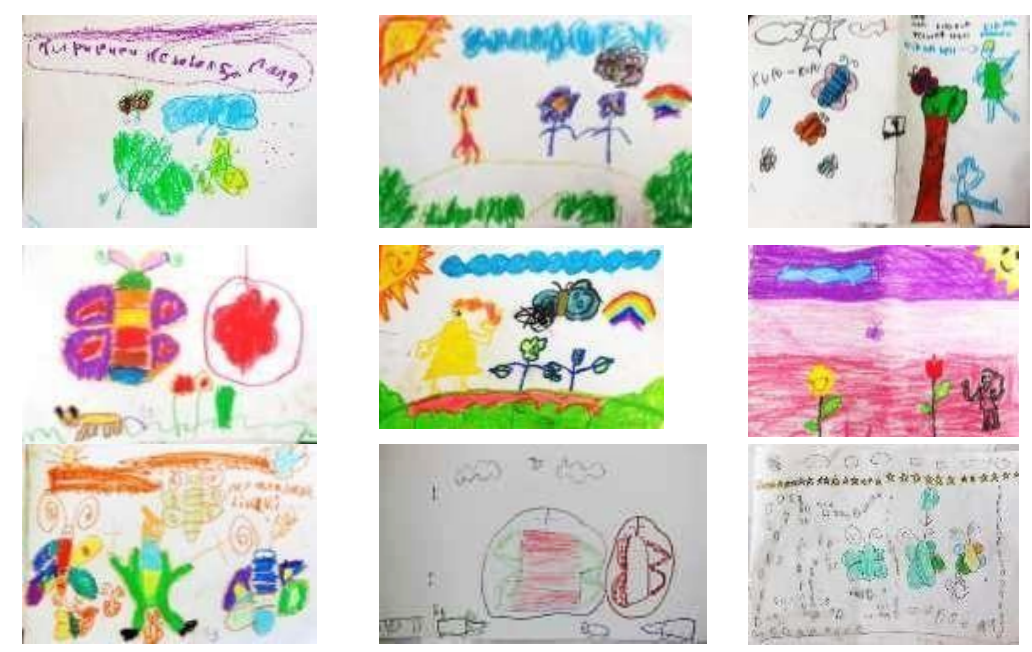

Picture 3. Image results drawing Learning Activities in UPI Laboratory Elementary School - Free Expression Method 


\section{c) SD Kuntum Cemerlang}

\section{Direct Learning Method (Directed Teaching)}

Direct learning method, applied by second grade teachers at Kuntum Cemerlang Elementary School, Bandung.

\section{KTSP Curriculum - Class 2, Semester 2}

- Competency Standards: 9. Express yourself through works of art

- Basic Competence: 9.1 Express yourself through expressive images

- Material: Simple perspective engineering drawings (far and near pictures).

- Instructions: To draw a forest scene.

- Conditions: - Draw objects with large and small sizes.

- The image is overlapping, there is an invisible part.

- The main object is made large.

- Using paper media, pencils, and markers.

The learning process in the second grade at Kuntum Cemerlang Elementary School is quite far from the KTSP curriculum (Depdiknas, 2014); the development is in the material theme, methods, and the goals of art learning. The curriculum approach used is included in demonstration. Schools provide as complete facilities as possible for self- development in terms of instructional media, rooms. The selection of materials uses what the school considers necessary for the development of children in the future. Implementation of the curriculum includes transmission orientation. In teaching and learning activities, children listen to information (the process of transferring knowledge); the teacher gives and waits for instructions, after getting active children's instructions but getting some references or provisions in drawing.

Table 8. Drawing Learning Activities at Kuntum Cemerlang Elementary School Direct Method

\begin{tabular}{lll}
\hline No & Activities & \multicolumn{1}{c}{ Information } \\
\hline 1. & $\begin{array}{l}\text { The teacher provides explanation and } \\
\text { understanding about drawing a simpler } \\
\text { perspective with the term "far-near picture". }\end{array}$ \\
\end{tabular}



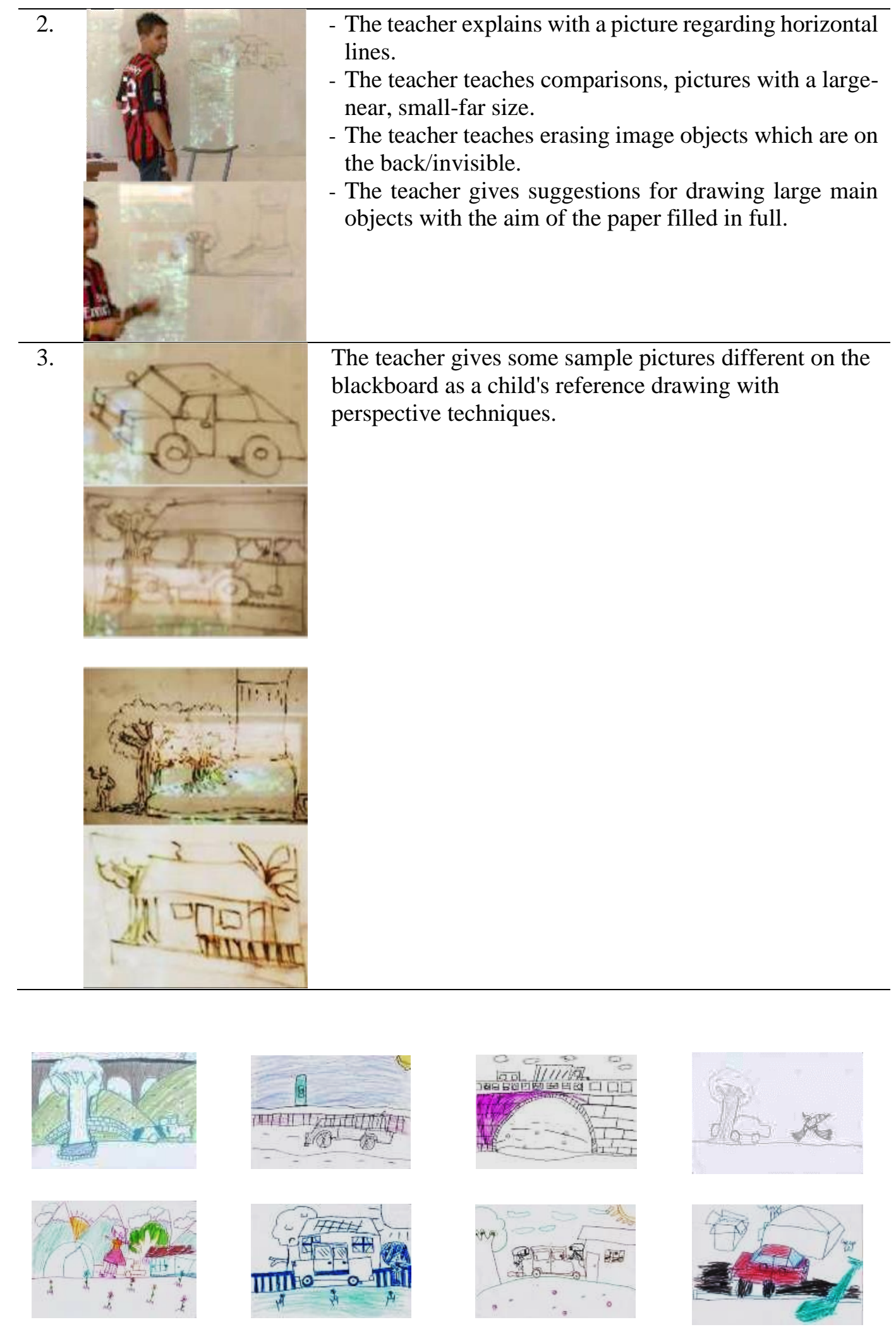

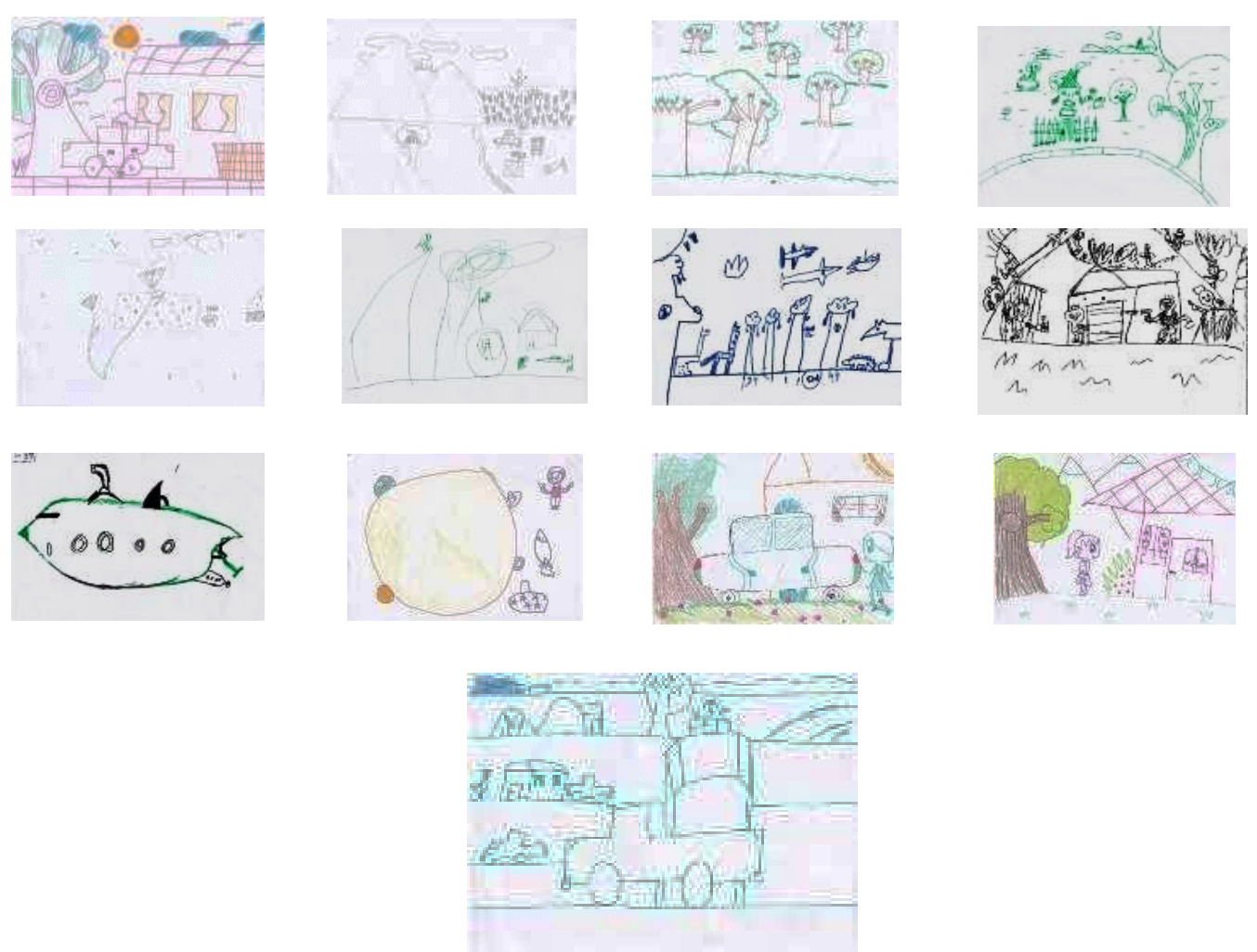

Picture 4. Image results drawing Learning Activities at Kuntum Cemerlang Elementary School - Direct Method

\section{Analysis of Image Results on Suitability of Visual Language Development}

This analysis is proof of the appropriateness of the application of the drawing learning method to the drawing results of each school and the suitability of the image results to the development of the visual language of children's drawings.

\section{a. Kelas 1 - UPI Laboratory Elementary School (Free Expression Method)}

Table 9. Results of Image Analysis Class 1 (Age 6-7 Years)

UPI Laboratory Elementary School

\begin{tabular}{|c|c|c|c|}
\hline No. & $\begin{array}{l}\text { Students } \\
\text { Total }\end{array}$ & Age & $\begin{array}{l}\text { Development of Visual Language } \\
\text { 6-7 Years }\end{array}$ \\
\hline 1. & 8 Students & 6 Years & Landline, not there yet. \\
\hline 2. & 19 Students & 7 Years & Perspective, simplified (stylized). \\
\hline 3. & 27 Students & 6-7 Years & Various visual languages are used. \\
\hline & Result & & 100\% Match \\
\hline
\end{tabular}

From the results of the data above, it is found that with a total of $100 \%$, the results of the children's drawings have conformity with the development of children's visual language in their age range. 


\section{b. Kelas 2 - Kuntum Cemerlang Elementary School (Direct Method)}

The number of second-grade students at Kuntum Cemerlang Elementary School in one class is 25 people; the number of students entered is 21 because of their absence. The sample images obtained are 21 pictures.

Table 10. Image analysis results for Class 1 (7-8 years old) Kuntum Cemerlang Elementary School

\begin{tabular}{|c|c|c|c|}
\hline No. & $\begin{array}{l}\text { Students } \\
\text { Total }\end{array}$ & Age & $\begin{array}{l}\text { Development of Visual Language } \\
\text { 6-7 Years }\end{array}$ \\
\hline 1. & 4 Students & 7 Years & $\begin{array}{l}\text { Landline, not there yet perspective, } \\
\text { simplified (stylized). Various visual } \\
\text { languages are used at once, head-to-toe } \\
\text { Important objects are magnified, X-rays. }\end{array}$ \\
\hline 2. & 17 Students & 8 Years & \\
\hline 3. & 21 Students & $\begin{array}{l}6-7 \\
\text { Years }\end{array}$ & $\begin{array}{l}\text { Not all pictures have the characteristics } \\
\text { of } 7-8 \text { years of age development }\end{array}$ \\
\hline \multirow[t]{2}{*}{ Result } & & 9 Students & 12 Students \\
\hline & & 42,85\% Match & $\begin{array}{l}57,14 \% \\
\text { Not Match }\end{array}$ \\
\hline
\end{tabular}

From the results of the data above, it is found that $42.85 \%$ of the results of the children's drawings have conformity with the development of children's visual language in their age range. While the remaining $57.14 \%$ of the results of the children's drawings do not have a conformity with the development of the visual language of the children's drawings, then from the number of pictures, $57.14 \%$ of the pictures will be further analyzed on the factors that influence developmental discrepancies with the results of the images.

\section{c. Class 2 - Banjarsari 5 Elementary School (Correlation Method)}

The number of students in grade 3 at Banjarsari 5 Elementary School in one class is 34 people; because of the absence of one student, the total sample of images obtained is 33 pictures.

Table 11. Results of Image Analysis Class 1 (Age 8-9 Years)

Banjarsari Elementary School

\begin{tabular}{llll}
\hline No. & Students Total & Age & $\begin{array}{l}\text { Development of Visual Language 6-7 } \\
\text { Years }\end{array}$ \\
\hline 1. & 10 Students & 8 Years & $\begin{array}{l}\text { Landline, not there yet perspective, simplified } \\
\text { (stylized). Various visual languages are used } \\
\text { at once, head-to-toe. } \\
\text { Important objects are magnified, X-rays. } \\
\text { Background layers, multiple ground lines, } \\
\text { twin, plural images, laying down, walking } \\
\text { around, flat, decorative. }\end{array}$ \\
\hline 2. & 23 Students & 9 Years & \\
\hline 3. & 33 Students & 8-9 Years & $\begin{array}{l}\text { All pictures have the characteristics of 8-9 } \\
\text { years old Fine Language development. }\end{array}$ \\
\hline & Result & $\mathbf{1 0 0 \%}$ Match & \\
\hline
\end{tabular}


From the results of the data above, it is found that as a whole with a total of $100 \%$, the results of the children's drawings have conformity with the development of children's visual language in their age range.

\section{CONCLUSION}

The conclusion in this study shows that the learning method does affect the results of children's drawings, and this proves the importance of choosing the right drawing learning method for children to suit their developmental age. The method of learning to draw is closely related to the images produced by each child. The learning method reflects the learning outcomes. If the method is applied to free expression and correlation, the image created is more varied and expressive. However, if the imitation method is applied, the results of the children's drawings will not be so varied by adding a mock image object from the sample image created. Choosing the right method and application for the child will result in the image's suitability with the development of the visual language of the child's drawing.

Learning methods for drawing that are effective for children aged six to nine include free expression and correlation methods. This is because this method is proven to have the potential to help children have the development of drawing according to their age in the theory of developing children's drawing visual language. In addition, this method is very effective in diverting children's attention to the objectives of the assessment or the final results achieved. The free and correlated expression method is able to position the teacher as a facilitator, motivator and innovator in building children's self-confidence when drawing. Because basically drawing activities for children, is one way of telling stories in visual form. Direct methods can be used for specific purposes in creating artificial forms, such as imitating nature, animals, plants or objects directly instead of imitating in the sense of prototyping creating image characters.

\section{Attachment}

The appendix contains information about the terms in the visual language development scheme for pictures of children aged 6-9 years and the term wimba I- V.

\begin{tabular}{lll}
\hline No. & $\begin{array}{l}\text { Development of Visual } \\
\text { Language }\end{array}$ & \multicolumn{1}{c}{ Explanation } \\
\hline 1. & Landline & $\begin{array}{l}\text { A line drawn at the bottom without a picture, } \\
\text { usually only a small amount of space. }\end{array}$ \\
\hline 2. & No perspective yet & There are no visible dimensions or sharp spaces. \\
\hline 3. & Simplified & Changed with simpler lines. \\
\hline 4. & Head to toe & Depicted in its entirety. \\
\hline 5. & Enlarged & The important part is enlarged. \\
\hline 6. & X-Ray & The invisible inner image is depicted. \\
\hline
\end{tabular}




\begin{tabular}{|c|c|c|}
\hline 7. & Image layer & A ground line separates each object. \\
\hline 8. & Plural landlines & There is a picture after the line. \\
\hline 9. & Twins image & $\begin{array}{l}\text { Important objects are described as equal and more } \\
\text { than one. }\end{array}$ \\
\hline 10. & Plural images & Objects are drawn multiple to indicate movement. \\
\hline 11 & Flat image & $\begin{array}{l}\text { The image is made without the impression of } \\
\text { dimensions. }\end{array}$ \\
\hline 12 & Decorative & The picture is more patterned. \\
\hline 13 & Minimized & The image is made smaller than other objects. \\
\hline 14 & Various looks & Can be seen from anywhere. \\
\hline 15 & Gigantic size & $\begin{array}{l}\text { The object is drawn the largest of the other } \\
\text { objects. }\end{array}$ \\
\hline 16 & Incident & Tell a scene. \\
\hline 17 & Representative & An image represents an object. \\
\hline 18 & $\begin{array}{l}\text { Direction sees right to left or } \\
\text { kinda. }\end{array}$ & $\begin{array}{l}\text { Depicted from the right first then left or vice } \\
\text { versa. }\end{array}$ \\
\hline 19 & $\begin{array}{l}\text { Direction see top to bottom or } \\
\text { kinda. }\end{array}$ & Drawn from top to bottom or vice versa. \\
\hline 20 & Direction see middle to edge. & Drawn from the center to the edge. \\
\hline 21 & Direction see edge to center. & Drawn from the edge to the center. \\
\hline 22 & Direction sees with one another. & Drawn from two directions together. \\
\hline 23 & Direction see chase. & Objects are drawn sequentially. \\
\hline 24 & Direction see average. & The object is depicted as equal. \\
\hline 25 & Direction sees get around. & Objects are drawn around from all parts. \\
\hline 26 & $\begin{array}{l}\text { Direction sees depicted from the } \\
\text { right first then left or vice versa } \\
\text { visible from anywhere. }\end{array}$ & Images can be interpreted from any direction \\
\hline
\end{tabular}

\section{REFERENCES}

De Francesco, I. L. (1958) Art Education, Its Means and Ends. New York: Haper \& Brother Publishers

Departemen Pendidikan Nasional (2014). Profil Pendidikan Provinsi Jawa Barat 2013-2014. Bandung: Subbag Perencanaan dan Program.

Duncum, Paul. (2008). Thinking Critically about critical thinking: towards a post critical, dialogic pedagogy for popular visual culture. International Journal of Education Through Art, volume 4 number 3, 248-250.

Duqquet, P. (1953). "Creative Communication Education and Art". [Symposium]. Paris: UNESCO.

Miler, J. P, dan Seller, W. (1985). Curriculum Perspectives and Practice. New York: Longman.

Sukmadinata, N, S. (2004). Kurikulum dan Pembelajaran Kompetensi.Bandung: Kesuma Karya.

Tabrani, P. (2012). Bahasa Rupa. Bandung: Kelir.

Tabrani, P. (2014). Proses Kreasi-Proses Belajar Anak. Jakarta: Erlangga. 